\title{
Adaptasi dan Kebiasaan Baru Human Resource Department di Masa Pandemik Covid-19
}

\author{
Muhammad Rizqi Agustino, Regy Citra Perdana, Dedi Hartawan, Yosart Adi Suyoso, Ratna Sari \\ agustino15rizqi@gmail.com
}

\begin{abstract}
This study aims to determine the adaptation and new habits of the company's HRD during the Covid-19 pandemic and to find out what policies are to anticipate the company's sustainability. The research method used is a qualitative method by conducting interviews with respondents in accordance with the requirements. The technique used is the documentation technique to collect data from various sources and information. The type of data is secondary data from the results of previous studies and information sourced from the media and news. It was found that since the spread of Covid-19 to the increase in the number of positive exposures in July 2020 the government made a PSBB policy and emphasized strict health protocols. This shift has an impact on the way HRD works in the company. Some large companies adapt and implement new normal habits as one of the policies to survive, and a small number of companies make a delay and cancel the work agenda.
\end{abstract}

Keywords: Covid-19, human resources, adaptation, new normal

Abstrak- Penelitian ini bertujuan untuk mengetahui adaptasi dan kebiasaan baru yang dilakukan HRD perusahaan dimasa pandemik Covid-19 serta untuk mengetahui kebijakan-kebijakan apa saja untuk mensiasati keberlangsungan perusahaan. Metode penelitian yang digunakan adalah metode kualitatif dengan melakukan wawancara kepada responden yang sesuai dengan persyaratan. Teknik yang digunakan yaitu teknik dokumentasi untuk mengumpulkan data dari berbagai sumber dan informasi. Jenis data berupa data sekunder hasil penelitian terdahulu dan informasi yang bersumber dari media dan berita. Ditemukan bahwa sejak terjadinya persebaran Covid-19 hingga melonjaknya jumlah paparan positif dibulan Juli 2020 pemerintah membuat kebijakan PSBB dan menekankan protokol kesehatan dengan ketat. Adanya pergeseran ini berdampak pada cara kerja HRD di perusahaan. Beberapa besar perusahaan melakukan adaptasi dan mengimplementasi kebiasaan baru sebagai salah satu kebijakan untuk bertahan, dan sebagian kecil perusahaan melakukan penundaan dan pembatalan agenda pekerjaan.

Kata kunci : Covid-19, sumber daya manusia, adaptasi, kebiasaan baru

\section{PENDAHULUAN}

Pandemik Covid-19 membawa perubahan dalam hal apapun, karena memberikan ancaman kesehatan dan keselamatan kerja dalam beraktifitas maupun pekerjaan. Aturan Pembatasan Sosial Skala Besar (PSBB) mulai diterapkan pada awal bulan April lalu di sejumlah kota besar di Indonesia sebagai salah satu upaya penanganan persebaran virus. Selain membuat kebijakan dan penerapan PSBB, sosialisasi protokol kesehatan juga gencar dilakukan oleh pemerintah pusat maupun pemerintah daerah untuk menekan persebaran dan angka positif tertularnya Covid-19. Kondisi ini tentu saja berdampak drastis terhadap kegiatan sosial, gaya hidup dan rutinitas masyarakat, khususnya daerah PSBB dan zona merah persebaran Covid-19.

Berdasarkan data Badan Nasional Penanggulangan Bencana (BNPB), jumlah paparan
Covid-19 meningkat secara drastis, tercatat pada bulan April 2020 sebanyak 5.923 kasus positif dan hingga 17 Juli 2020 melonjak tajam sekitar 83.000 kasus positif yang tersebar di 34 provinsi. Kondisi ini memaksa perubahan dan menghasilkan keputusan-keputusan baru sebagai salah satu bentuk dukungan untuk mengurangi persebaran yang semakin meluas dan sebuah langkah adaptasi untuk membentuk kebiasaan baru dalam menghadapi wabah pandemik. Beberapa perusahaan menghentikan aktivitas bisnis, penundaan operasional perusahaan, merombak strategi bisnis, melakukan pemutusan hubungan kerja, menunda proses rekutmen, maupun tetap melakukan aktivitasnya dengan mengikuti protokol kesehatan dengan ketat.

Seiring berjalannya waktu, trend ini mendorong lebih banyak perusahaan-perusahaan 
lain untuk berbenah dan beradaptasi sebaik mungkin agar tetap bisa bertahan, salah satu divisi yang berdampak penuh terhadap pergeseran ini adalah divisi HRD. Tanggung jawab HRD tidak hanya pada keadaan dan kondisi perkembangan perusahaan, HRD juga menjadi garda terdepan dalam penanganan tenaga kerja yang sampai saat ini masih menjadi topik hangat dikalangan perusahaan bahkan dibahas secara nasional. Mulai dari pengurangan tenaga kerja, pemotongan upah, peniadaan benefit, perubahan pelaksanaan rekrutmen hingga tantangan di masa pemulihan seperti pembagian waktu kerja (offline/online), bekerja secara daring, beralih menggunakan sistem dan teknologi, perhitungan penggajian, pembaruan absensi karyawan dan memastikan perusahaan menerapkan dan penyediaan fasilitas protokol kesehatan. Penelitian ini bertujuan untuk mengetahui adaptasi dan kebiasaan baru yang dilakukan HRD perusahaan dimasa pandemik Covid-19 serta untuk mengetahui kebijakankebijakan apa saja untuk mensiasati keberlangsungan perusahaan.

\section{Human Resource}

\section{KAJIAN PUSTAKA}

Human resource (HR) merupakan sebuah konsep, ataupun fungsi yang terdiri dari bidang dan unit tugas yang memiliki sekumpulan pengetahuan, keterampilan dan kemampuan untuk memberikan layanan profesional bagi organisasi guna memaksimalkan sumber daya manusia, meningkatkan efektifitas dan efisiensi bagi organisasi. HR mencakup beberapa bidang dengan fungsi yang berbeda, antara lain bidang perencanaan, administrasi \& sistem informasi, rekrutmen \& seleksi, pelatihan \& pengembangan, manajemen kinerja, penggajian \& kompensasi, hubungan industrial, serta pengembangan organisasi.

\section{Adaptasi}

Menurut Denison (1995), teori adaptasi merupakan penekanan pada kemampuan organisasi untuk menyesuaikan diri terhadap lingkungan, menerima, menafsirkan dan menerjemahkan gangguan ataupun perubahan dari eksternal ke dalam norma-norma internal organisasi yang berdampak terhadap keberlangsungan dan ketahanan sebuah organisasi. Sebagai upaya kesuksesan adaptasi, organisasi harus memiliki persepsi dan respon terhadap lingkungan, kemampuan untuk menanggapi kondisi internal serta memiliki raksi cepat terhadap perubahan.

\section{Kebiasaan Baru}

Kebiasaan baru (New Normal) memiliki definisi yang berbeda menyesuaikan sudut pandang dari beberapa kepentingan dan institusi. Secara umum new normal merupakan sebuah cara atau tatanan baru dalam menjalani kehidupan dan aktivitas sehari-hari. Menurut pakar kesehatan dan dilihat dari perspektif kesehatan, agar suatu daerah atau negara dapat mengimplementasikan new normal harus memenuhi beberapa persyaratan, antara lain daerah tersebut sudah terbukti mengalami perlambatan kasus persebaran virus, sudah dilakukannya PSBB secara maksimal, kondisi masyarakat yang siap dan mampu memenuhi kebutuhan daya tahan tubuh serta tersedianya infrastruktur yang memadai untuk mendukung aktivitas sehari-hari. Dari perspektif sosial, new normal merubah perilalu masyarakat untuk lebih berhati-hati dan mengurangi kontak langsung seperti jabat tangan, cipika-cipiki dan berkumpul. Sedangkan dari sisi ekonomi dan bisnis, new normal menggeser bisnis model menjadi serba digital dan bergantung pada teknologi. Sedang pemerintah Indonesia mendefinisikan new normal sebagai membudayakan hidup bersih dan sehat dengan rajin melakukan cuci tangan, menggunakan masker, menjaga jarak dan menghindari kerumunan.

\section{METODE PENELITIAN}

Menggunakan metode riset kualitatif dengan menekankan pengembangan pertanyaan riset, penentuan responden yang tepat dan kualitas data 
yang diperoleh (Cooper \& Schindler, 2014). Teknik pengumpulan data dilakukan dengan wawancara kepada responden yang memenuhi persyaratan yaitu dengan kriteria responden yang bekerja di bidang HRD dalam enam bulan teakhir. Serta menggunakan teknik dokumentasi sebagai suatu cara untuk mengumpulkan data dari berbagai sumber dan informasi. Jenis data berupa data sekunder hasil penelitian terdahulu terhadap 77 responden yang bekerja di bidang HRD dengan masa jabatan lebih dari dua tahun. Data sekunder adalah data yang mengacu pada informasi yang dikumpulkan dari sumber yang telah ada (Sekaran, 2011).

\section{HASIL DAN PEMBAHASAN}

1. Berdasarkan hasil wawancara, lima responden mengatakan perusahaan sudah beradaptasi dan menerapkan protokol kesehatan dan mengimplemetasikan WFH secara parsial, artinya selain bekerja secara daring, karyawan juga memiliki jadwal kerja di kantor.

2. Rutinitas dan aktivitas kerja HRD selama pandemik mengalami perubahan dan modifikasi secara signifikan dan dalam hal rekrutmen mayoritas masih melakukan seperti biasa dengan fokus kebutuhan tenaga kerja berkemampuan dibidang teknik, teknologi, software dan digital.

3. Perusahaan dan HRD sudah siap menghadapi tantangan dan menyusun strategi untuk jangka panjang selama pandemic Covid-19 terjadi hingga ditetapkan sebagai kebiasaan baru.

4. Dari hasil penelitian sebelumnya dengan 77 karyawan yang bekerja di bidang HRD mengungkapkan bahwa sebesar $80 \%$ telah mengimplementasikan bekerja secara daring dari rumah, $15 \%$ mengimplementasikan sebagian tetap bekerja dikantor dan sebagian secara daring, serta $5 \%$ tetap melaksanakan aktivitas kerja dikantor secara penuh.

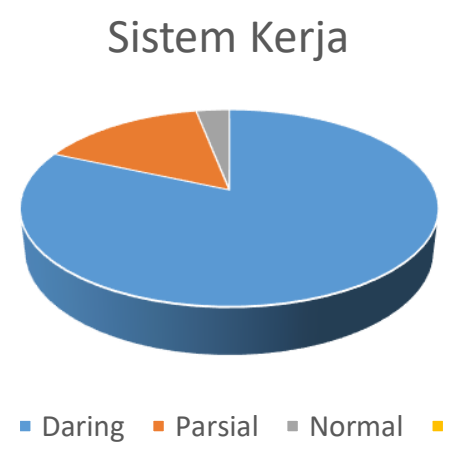

Sumber : Diolah peneliti, 2020

5. Penelitian juga mengungkapkan dampak pandemik terhadap rutinitas HRD saat bekerja. Tecatat sebesar $66 \%$ HRD tetap melakukan pekerjaan rutinitas dengan beberapa perubahan dan modifikasi,20\% mengatakan mengalami penundaan, $10 \%$ melakukan pembatalan, serta $4 \%$ merasa tidak ada perubahan dalam melaksanakan perkerjaan.

\section{Rekrutmen}

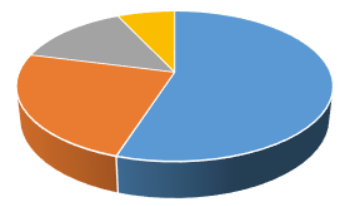

- Non - Pembatasan - Normal - Penambahan

Sumber : Diolah peneliti, 2020

6. Terdapat sekitar $15 \%$ projek rekrutmen, pengembangan organisasi dan pengembangan karyawan mengalami pembatalan, sedangkan projek yang berbasis digital, e-commerce dan telekomunikasi sebesar 3\% tetap menjalankan projeknya.

7. Berdasarkan data pelaksanaan rekrutmen dari 100 karyawan di perusahaan dan industri berbeda, sebanyak 55 perusahaan tidak melakukan rekrutmen, 24 perusahaan tetap 
melakukan rekrutmen dengan pembatasan jumlah, 14 perusahaan tetap melakukan sesuai perencanaan dan 7 perusahaan lebih banyak melakukan proses rekrutmen.

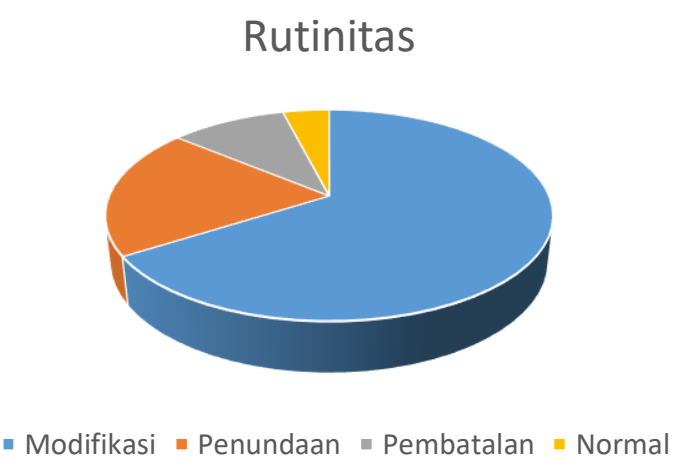

Sumber : Diolah peneliti, 2020

8. Dari 100 perusahaan, mayoritas perusahaan mencari tenaga kerja yang berlatar belakang IT dan Software sebanyak 3 perusahaan, 28 di bidang operasi dan pelaksanaan, serta 24 perusahaan dibidang pemasaran.

\section{KESIMPULAN DAN SARAN}

Pandemik Covid-19 yang merupakan wabah yang tersebar diseluruh dunia termasuk di Indonesia benar-benar memberikan pengaruh dan dampak yang luar biasa bagi HRD di seluruh perusahaan apapun industrinya. Dimasa adaptasi dan kebiasaan baru, HRD dan perusahaan dituntut untuk mempelajari dan memahami lebih dalam mengenai protokol kesehatan dan hal-hal mengenai keamanaan dan keselamatan bekerja. Sebagai bentuk penyesuaian dan upaya agar perusahaan tetap bertahan, perusahaan dan HRD harus mengeluarkan beberapa kebijakan yang bersifat positif dan negatif. Di sisi positif, beberapa perusahaan membuka kesempatan kerja khusus tenaga ahli di bidang teknologi dan digital. Disisi negatif, perusahaan terpaksa melakukan pemutusan hubungan kerja dan melakukan pemotongan upah kerja. Untuk lebih siap menghadapi kondisi bisnis dimasa datang, perusahaan dan HRD hendaknya lebih responsif terhadap isu global, sehingga menjadi lebih siap menghadapi perubahan untuk meminimalisir kebijkan yang merugikan pihak lain.

\section{REFERENSI}

[1] Cooper dan Schindler. (2014). Bussiners Research Method. New York: McGrawHill.

[2] Denison, Daniel R. (1995). Toward a theory of organizational culture and effectiveness. Organization Science. Vol 6.

[3] How Indonesian Employers Respond to COVID19 Crisis. 2020. Jakarta. Glints Global.

[4] Sekaran, Uma. 2011. Research methods for business (Metode penelitian untuk bisnis). Jakarta: Salemba Empat.

[5] https://bnpb.go.id/berita/sebanyak-10-daerahtetapkan-psbb-demi-putus-penularan-covid19. Diakses 17 Juli 2020. Pukul 13.15.

[6] https://www.bnpb.go.id/index.php/infografis/inf ografis-update-dampak-covid19-tgl-17-april2020. Diakses 17 Juli 2020. Pukul 14.00.

[7] https://tirto.id/syarat-new-normal-dari-whonegara-sudah-mampu-kendalikan-covid-19-

fDnC. Diakses 17 Juli 2020. Pukul 14.10.

[8] https://tirto.id/arti-new-normal-indonesiatatanan-baru-beradaptasi-dengan-covid-19fDB3. Diakses 17 Juli 2020. Pukul 14.15.

[9] https://nasional.kompas.com/read/2020/07/17/16 065621/update-17-juli-tambah-1489-pasiencovid-19-sembuh-dari-covid-19-jadi-41834. Diakses 17 Juli. Pukul 23.00. 